\title{
表面プラズモン共鳴を用いた光タクタイル圧力センサ
}

\author{
正員 沼田 孝之* 非会員 岩崎 吉朗* \\ 正 員 大谷 幸利* 非会員 梅田 倫弘*
}

\section{Opto-Tactile Pressure Sensor Using Surface Plasmon Resonance}

Takayuki Numata*, Member, Yoshiro Iwasaki*, Non-member, Yukitoshi Otani*, Member, Norihiro Umeda*, Non-member

An optical tactile pressure sensor using surface plasmon resonance is reported. A colloidal crystalline membrane of elastic polymer particles $(n=1.59)$ is pressed against a surface of Au film on a glass prism $(n=1.51)$ where SPR is excited. At the contact area between the particle and Au film, excitation condition of SPR is broken and the incident light internally reflects. Since the contact area changes reversibly according to the loaded pressure, optical measurement of pressure is realized by monitoring the intensity of reflection light. Measurement of $5 \mathrm{MPa}$ was achieved by the proposed method.

キーワード : 表面プラズモン共鳴, 弾性高分子, 接触, 光学式, タクタイルセンサ, 圧カセンサ

Keywords : Surface Plasmon Resonance, Elastomer, Contact, Optical, Tactile sensor, Pressure sensor

\section{1. はじめに}

光学式の圧力センサは, 電磁ノイズや多湿環境下での動 作が可能なことから，建築工学をはじめ様々な分野で利用 されている。特に，プリズム表面のエバネセント場中に弾 性体を挿入し, 荷重に応じて起こる光波の散乱を検出する 光タクタイル式センサは, 触圧分布の画像化が可能なため 指紋認証システム等への応用が期待されるが，高い空間分 解能（微小領域での圧力検出）とダイナミックレンジとの 間のトレードオフや, 低 SN 比という感度的な問題がある ${ }^{(1)}$ 。 一般に，エバネセント場における光強度は非常に微弱であ るが，プリズム表面に形成した金属薄膜に表面プラズモン 共鳴（SPR）を励起させることで数十倍以上に増強されるこ とが知られている。すなわち, SPR を光散乱型圧力センサ に導入することで SN 比の改善や, 検出圧力帯域の拡大が期 待できる。本稿では, SPR を用いた光タクタイル式圧力セ ンサを試作したので報告する。

\section{2. 検出原理}

〈2·1〉表面プラズモン共鳴＼cjkstart表面プラズモン共鳴 （SPR）は，金属中の自由電子の共鳴的な集団振動であり， その励起には，金属への入射電磁場と電子の粗密波との波 数の整合が必要である(2)。一般に SPR の励起には, Kretschmann 配置と呼ばれる, プリズム表面の金属薄膜をプ

\footnotetext{
* 東京農工大学 工学部

干184-8588 東京都小金井市中町 2-24-16

Fac. of Eng., Tokyo University of Agriculture and Technology Nakacho 2-24-16, Koganei, Tokyo 184-8588
}

リズム側から全反射照明する方法が採られる。SPR の励起 に費やされた光のエネルギは金属内に吸収され, 反射光が 減衰する（図 1(a)）。一方, プリズム表面での全反射条件が (a) $\mathrm{n}_{1}<\mathrm{n}_{2}$

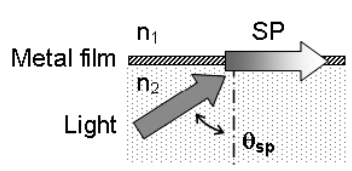

(c)

(c)

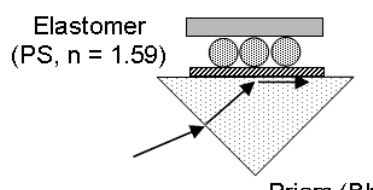

Prism $(B K 7, \mathrm{n}=1.51)$
図 1 表面プラズモン共鳴と圧力測定原理

Fig. 1. Principles of pressure measurement with SPR
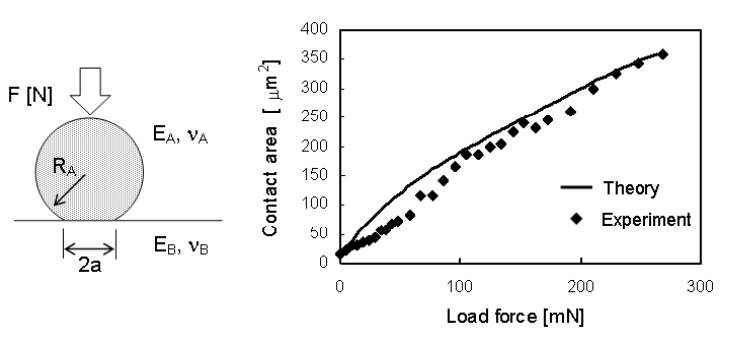

図 2 ヘルツ理論による接触面積の解析と検証

Fig. 2. Study on contact area based on Hertz theory 


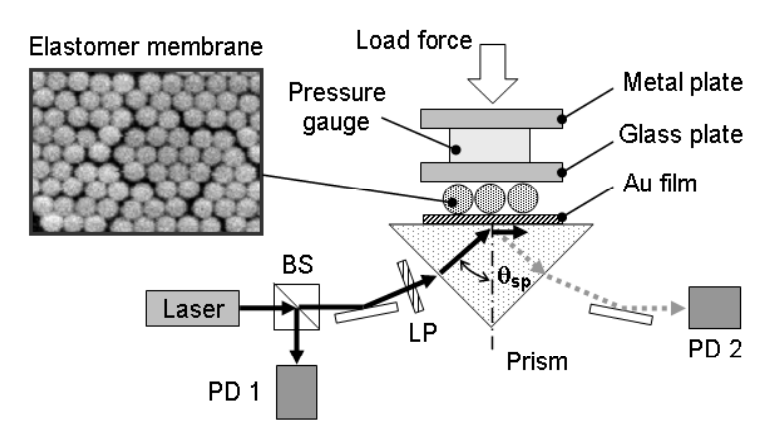

図 3 実験装置とコロイド結晶膜の SEM 像

Fig. 3. Experimental setup and a SEM micrograph of crystalline membrane with PS particles $(\phi=200 \mathrm{~nm})$

崩れると, SPR は励起されず入射光のエネルギは金属膜に よって反射される（図 1(b)）。本研究では，図 1(c)に示すよ うに，プリズム（BK7, $\mathrm{n}=1.51 ）$ に対して大きな屈折率を 持つポリスチレン（PS, $\mathrm{n}=1.59 ）$ 微粒子の二次元コロイド 結晶膜を弾性接触子として用いる。これを, SPR を励起し た金属膜上に配置し，負荷を加えることで変形させ，金属 膜との接触面積を増減させる。接触部では SPR が励起され ず，反射光強度が増大する。荷重による接触面積の増減を 利用して SPR の励起面積を変化させることで, 荷重（圧力） を光強度に変換し検出する。

$\langle 2 \cdot 2\rangle$ 荷重と接触面積 鉛直荷重に対する金属膜と 弾性体粒子の接触面積の変化を, ヘルツの弾性接触理論を 用いて検証した。実験は, ガラス基板上の PS 球 $(\phi=20 \mu \mathrm{m})$ を圧電素子を用いて鉛直方向に荷重し，画像処理によって 接触面積を算出する。図 2 にモデルと理論曲線，および測 定值を示す。図中の $\mathrm{E}, v$ はそれぞれヤング率, ポアソン比, 添え字 A，B はポリスチレン，ガラスを表す。実験值と理論 值はほぼ一致し, PS 球を接触子とした場合, 接触面積が負 荷荷重によって変化することを確認した。

\section{3. 実験装置}

図 3 に実験装置の概略を示す。光源には $\mathrm{He}-\mathrm{Ne}$ レーザ $(\lambda$ $=632.8 \mathrm{~nm}$ ) を用いた。レーザ出射光をビームスプリッタ （BS）で二分割し一方を参照用検出器（PD 1）に導く。この 值は測定においてレーザ強度の摇らぎを相殺するために用 いられる。もう一方は直線偏光子（LP）によって P 偏光と された後, SPR 励起角度 (共鳴角, $\theta_{\mathrm{sp}}$ ) でプリズム表面の 厚さ約 $50 \mathrm{~nm}$ の金薄膜を照明する。金薄膜は, プリズムを 脱脂洗浄した後，スパッタリングにより作製した。プリズ ム表面からの減衰反射光はPD 2 で検出される。金薄膜上に は PS 球のコロイド結晶膜を配置する。そこへガラス基板, 荷重モニタ用の圧力計, および金属平板を介して鉛直方向 に荷重を加える。荷重は直流モータを用いた並進アクチュ エータにより段階的に負荷した。一定荷重に対する圧力計 の出力が安定した後，反射率を測定，記録する。

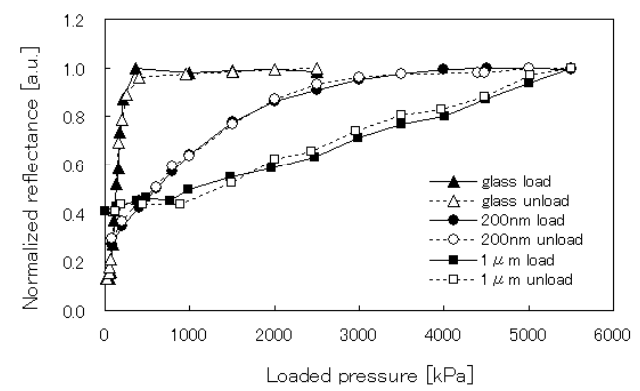

図 4 圧力一反射率測定結果

Fig. 4. Loaded pressure versus reflectance

\section{4. 結果と考察}

光学系を SPR の共鳴角に保持した状態で, プリズム表面 の弾性接触子膜に荷重を加えていく。図 4 に測定結果を示 す。弾性体には, 直径 $200 \mathrm{~nm}, 1 \mu \mathrm{m}$ の PS 球結晶膜, また 参考に準剛体試料としてガラス基板を用いた。弾性試料の 場合，印加圧力に緩やかに依存した反射率曲線が得られた。 特に $1 \mu \mathrm{m}$ の試料では, ほぼ線形な応答が得られた。ガラス 基板の場合は, 無負荷時に存在した金薄膜との微小な間隙 が基板のたわみによって埋まり, 反射率が急増する。一方, $200 \mathrm{~nm}$ の試料では, 両者の中間的な検出特性が得られた。 即ち, 接触子のサイズや形状によって検出感度の調節が可 能であるといえる。無負荷に対する信号飽和時の反射光強 度コントラストは，接触子の粒子サイズが小さい程大きく なる傾向が得られた。また検出曲線は負荷および除荷過程 でほぼ同一の軌跡をたどる。これは, 接触子の弾性変形に よるもので, 本センサの応答が可逆的であり, 負荷, 除荷 過程の繰り返し測定が可能であることを示している。

\section{5. まとめ}

SPR を用いた光タクタイル式圧力センサを提案, 試作し た。その結果, 負荷圧力に応じた光強度の変化を検出した。 接触子の弾性係数や面積, 密度, サイズの適正化により, 測定レンジや感度の調整が可能であると考えられる。また, ナノサイズの接触子アレイは, 結像光学系や $\mathrm{CCD}$ 等の二次 元検出器と組み合わせることで, 微小領域における圧力分 布の高解像度なイメージングが期待できる。本研究成果は, 光学式圧力センサの感度向上, および新規感圧光学素子の 可能性を示すものである。

(平成 18 年 9 月 28 日受付)

\section{文献}

(1) M. Yamazaki : "Tactile Imaging Sensors Using Optical Tunneling Effect", Sensing Forum, Vol.14, pp.157-161 (1997) (in Japanese) 山崎正之：「光トンネル効果を使った触覚映像センサー」, センシン グフォーラム資料, 14, pp.157-161 (1997)

(2) H. Raether : Surface Plasmons on Smooth and Rough Surfaces and on Gratings, p.11, Springer-Verlag, Berlin (1988) 